Tropical Journal of Pharmaceutical Research, April 2009; 8 (2): 133-137

(c) Pharmacotherapy Group,

Faculty of Pharmacy, University of Benin

Benin City, 300001 Nigeria.

All rights reserved.

Research Article

Available online at http://www.tjpr.org

\title{
Anti-Inflammatory and Antipyretic Activities of Hygrophila spinosa T. Anders Leaves (Acanthaceae)
}

\author{
Arjun Patra ${ }^{1^{*}}$, Shivesh $\mathrm{Jha}^{2}$, P. Narasimha Murthy ${ }^{3}$, Aher Vaibhav D. ${ }^{1}$, \\ Pronobesh Chattopadhyay ${ }^{1}$, Ghanshyam Panigrahi ${ }^{3}$ \& Devdeep Roy ${ }^{4}$ \\ ${ }^{1}$ College of Pharmacy, IFTM, Moradabad- 244 001, U.P., ${ }^{2}$ Department of Pharmaceutical Sciences, Birla Institute of \\ Technology, Mesra-835 215, Ranchi, Jharkhanda, ${ }^{3}$ Royal College of Pharmacy \& Health Sciences, Berhampur-760 \\ 002, Orissa, India, ${ }^{4}$ Master of Research Biomedical Sciences, Department of Immunology, University of Strathclyde, \\ Glasgow, Scotland.
}

\begin{abstract}
Purpose: Hygrophila spinosa T. Anders (Acanthaceae) is commonly used in the traditional system of medicine for the treatment of inflammation, pain, jaundice, rheumatism, arthritis, anaemia, etc. In the present study, we investigated the anti-inflammatory and antipyretic activities of the petroleum ether, chloroform, alcoholic and aqueous extracts of the leaf of this plant.
\end{abstract}

Methods: The anti-inflammatory activity of the various extracts was studied based on their effects on carrageenan-induced paw oedema in rats while antipyretic activity was evaluated on the basis of their effect on Brewer's yeast-induced pyrexia in rats. The extracts were screened for alkaloids, steroids, proteins, flavonoids, saponins, mucilage, carbohydrates, organic acids, fats and oils.

Results: Preliminary phytochemical screening revealed the presence of alkaloids, steroids, proteins, flavonoids, fats and oils, tannins, mucilage and organic acids in the leaves of $H$. spinosa. Chloroform and alcoholic extracts of leaves of $H$. spinosa produced significant ( $p<$ 0.05 and $p<0.01)$ anti-inflammatory and antipyretic activities in a dose-dependent manner.

On the other hand, petroleum ether and aqueous extracts did not show significant

anti-inflammatory and antipyretic activities. The maximum anti-inflammatory activities produced by chloroform and alcoholic extracts (400 mg/kg) were $33.7 \%$ and $47.5 \%$, respectively. These two extracts also reduced elevated body temperature in rats at 200 and $400 \mathrm{mg} / \mathrm{kg}$ body weight doses throughout the observation period of $6 \mathrm{~h}$.

Conclusion: Chloroform and alcoholic extracts of $H$. spinosa leaves have anti-inflammatory and antipyretic activities.

Keywords: Hygrophila spinosa, anti-inflammatory activity, antipyretic activity, leaf extracts 


\section{Introduction}

Hygrophila spinosa T. Anders (Acanthaceae) is commonly found in water-logged areas throughout India'. The plant is used as a diuretic and for the treatment of rheumatism, jaundice, inflammation, pain, hepatic obstruction, gout, bacterial infection etc ${ }^{2-6}$. The aerial parts of the plant are reported to contain lupeol, stigmasterol and butelin while the seeds mainly contain fatty acids ${ }^{7}$. Its root contains an alkaloid named hygrosterol ${ }^{8}$ while its flower contains apigenin 7-o-glucuronide ${ }^{9}$. However, no data were found regarding the pharmacological and phytochemical evaluation of the leaves of the plant. The aim of the present study is to investigate the antiinflammatory and antipyretic properties of the petroleum ether, chloroform, alcoholic and aqueous extracts of the leaves of $H$. spinosa.

\section{Material and Methods}

\section{Drugs and reagents}

Tween 80 (Lobachem, India), Indomethacin (MicroLab, India), carrageenan (Sigma), Brewer's yeast (Tetragon Chemie), and paracetamol (GlaxoSmithKline) were used in the study.

\section{Plant material}

The leaves of $H$. spinosa were collected from Berhampur, Orissa, India. The plant was identified by Dr. N. K. Dhal, Scientist, Regional Research Laboratory, Bhubaneswar, India and a voucher specimen (no. 9999) was preserved for further references.

\section{Preparation of extracts}

The leaves were washed thoroughly, dried under a shade and pulverized. The coarse powder was extracted successively with petroleum ether, chloroform and alcohol using a soxhlet apparatus. Finally, the aqueous extract was prepared by decoction. The extracts were dried using a rotary vacuum evaporator and stored in a desiccator until further use.

\section{Animals}

Wistar rats of both sexes, weighing $150-200$ $g$ were used for the study. The animals were kept in polypropylene cages in a room maintained under controlled atmospheric conditions. The animals were fed with standard diet (Hindustan liver, Mumbai, India) and had free access to clean drinking water. The experimental protocol was approved by the Institutional Animal Ethics Committee (IAEC) of Royal College of Pharmacy and Health Sciences Berhampur, Orissa, India.

\section{Anti-inflammatory activity}

The anti-inflammatory activity of the extracts was determined according to the method of Borgi et $a l^{10}$ and Vogel et al ${ }^{11}$. The rats were divided into ten groups of six rats each. The control group received $1 \%(\mathrm{v} / \mathrm{v})$ Tween 80 in water, p.o. at a dose of $10 \mathrm{ml} / \mathrm{kg}$. The positive control group was treated orally with the standard drug, indomethacin $(10 \mathrm{mg} / \mathrm{kg})$. Different extracts were administered to the other groups in doses of 200 and $400 \mathrm{mg} / \mathrm{kg}$ as shown in Table 1. All the suspensions were administered $30 \mathrm{~min}$ before the induction of oedema by administering $0.1 \mathrm{ml}$ of $1 \% \mathrm{w} / \mathrm{v}$ carrageenan in saline ${ }^{12,13}$. The degree of paw oedema of all the groups was measured using a plethysmometer at 30,60, 120, 180 and 240 min after the administration of carrageenan to each group.

\section{Antipyretic activity}

Animals were selected for the experiment after confirmation of approximate constant rectal temperature for 7 days. The antipyretic activity of the extracts was evaluated based on Brewer's yeast-induced pyrexia in rats ${ }^{14,15}$. Pyrexia was induced by subcutaneous injection of $10 \mathrm{ml} / \mathrm{kg}$ of $15 \% \mathrm{w} / \mathrm{v}$ Brewer's yeast suspension below the nape of the neck. The rectal temperature of each rat was measured at time, $0 \mathrm{~h}$, using a telethermometer and before injection of the yeast. At $18 \mathrm{~h}$ following yeast injection, the different groups were treated with the vehicle, extracts $(200$ and $400 \mathrm{mg} / \mathrm{kg}$ ) and standard 
drug, paracetamol $(150 \mathrm{mg} / \mathrm{kg})$. The rectal temperature was then recorded over a period of $6 \mathrm{~h}$.

\section{Statistical analysis}

The results were expressed as mean \pm S.E.M. Statistical analysis of the data were carried out using Student's t-test and results were considered significant when $p<0.05$.

\section{Results}

\section{Anti-inflammatory activity}

The chloroform and alcoholic extracts of $H$. spinosa produced significant $(p<0.05)$ antiinflammatory activity, while petroleum ether and aqueous extracts did not. Significant reduction of paw oedema was observed 30 min and $3 \mathrm{~h}$ after carrageenan injection, for alcoholic and chloroform extracts, respectively. The reduction in carrageenaninduced paw oedema by $400 \mathrm{mg} / \mathrm{kg}$ of chloroform and alcoholic extracts after $4 \mathrm{~h}$ was 43.7 and $47.5 \%$, respectively, while oedema reduction by the standard drug, indomethacin $(10 \mathrm{mg} / \mathrm{kg}$ ) was $53.7 \%$ (see Table 1).

\section{Antipyretic activity}

Chloroform and alcoholic extracts produced significant antipyretic activity $(p<0.05)$, but petroleum ether and aqueous extracts did not. Chloroform extract significantly decreased the elevated rectal temperature $3 \mathrm{~h}$ after the administration of a dose of $400 \mathrm{mg} / \mathrm{kg}$ only, while the alcoholic extract reduced the hyperthermia at both 200 and $400 \mathrm{mg} / \mathrm{kg}$ doses $1 \mathrm{~h}$ after administration. The initial and final rectal temperatures in the groups treated with chloroform extract $(400 \mathrm{mg} / \mathrm{kg}$ ), alcoholic extract $(400 \mathrm{mg} / \mathrm{kg})$ and paracetamol (150 $\mathrm{mg} / \mathrm{kg}$ ) were $38.03 \pm 0.16$ and $37.41 \pm 0.26$, $38.55 \pm 0.14$ and $37.81 \pm 0.19$, and $38.70 \pm$ 0.15 and $37.87 \pm 0.18{ }^{\circ} \mathrm{C}$, respectively. Paracetamol and alcoholic extract showed significant antipyretic activity throughout the test period of $6 \mathrm{~h}$ (see Table 2).

\section{Discussion}

Carrageenan-induced paw oedema is a commonly used primary test for the screening of new anti-inflammatory agents and is believed to be biphasic ${ }^{16}$. The first phase (1-2 $\mathrm{hr}$ ) is due to the release of histamine or serotonin and the second phase of oedema is due to the release of prostaglandin ${ }^{17,18}$. The results of this study indicate that the chloroform and alcoholic extracts of $H$. spinosa significantly reduced carrageenaninduced paw oedema in rats. Therefore, the mechanism of action may be by inhibition of histamine, serotonin or prostaglandin synthesis.

Usually most anti-inflammatory and analgesic drugs possess antipyretic activity. In general, non-steroidal anti-inflammatory drugs produce their antipyretic action through the inhibition of prostaglandin synthetase within the hypothalamus $^{19}$. Therefore, the antipyretic activity of chloroform and alcoholic extracts of $H$. spinosa is probably by inhibition of prostaglandin synthesis in hypothalamus.

Preliminary phytochemical screening revealed the presence of alkaloids, flavonoids, steroids in the chloroform extract, as well as alkaloids, flavonoids, tannins and steroids in the alcoholic extract of the leaves of $H$. spinosa ${ }^{20}$. The anti-inflammatory and antipyretic potentials of alkaloids, steroids and flavonoids have been reported in various studies ${ }^{21-23}$. Therefore, the anti-inflammatory and antipyretic activities of the chloroform and aqueous extracts may be due to the presence of alkaloids, sterols and flavonoids.

\section{Conclusion}

The results of the present study indicate the anti-inflammatory and antipyretic activities of 
Patra et al

Table 1: Effect of extracts of $H$. spinosa leaf on paw oedema induced by carrageenan in rats

\begin{tabular}{|c|c|c|c|c|c|c|}
\hline \multirow{2}{*}{ Treatment } & \multirow{2}{*}{$\begin{array}{c}\text { Dose } \\
(\mathrm{mg} / \\
\mathrm{kg})\end{array}$} & \multicolumn{5}{|c|}{ Increase in paw volume (in $\mathrm{ml}$ ) after various times } \\
\hline & & $30 \mathrm{~min}$ & $1 \mathrm{~h}$ & $2 \mathrm{~h}$ & $3 \mathrm{~h}$ & $4 \mathrm{~h}$ \\
\hline Control & - & $0.26 \pm 0.02$ & $0.40 \pm 0.04$ & $0.73 \pm 0.04$ & $0.88 \pm 0.05$ & $0.80 \pm 0.05$ \\
\hline Indomethacin & 10 & $0.18 \pm 0.04^{*}$ & $0.23 \pm 0.02^{* *}$ & $0.35 \pm 0.02^{* \star}$ & $0.43 \pm 0.05^{\star *}$ & $0.37 \pm 0.03^{* *}$ \\
\hline \multirow[t]{2}{*}{ HSPE } & 200 & $0.28 \pm 0.06$ & $0.45 \pm 0.07$ & $0.68 \pm 0.07$ & $0.86 \pm 0.07$ & $0.71 \pm 0.08$ \\
\hline & 400 & $0.25 \pm 0.05$ & $0.42 \pm 0.05$ & $0.66 \pm 0.07$ & $0.78 \pm 0.05$ & $0.75 \pm 0.04$ \\
\hline \multirow[t]{2}{*}{$\mathrm{HSCH}$} & 200 & $0.23 \pm 0.04$ & $0.32 \pm 0.04$ & $0.55 \pm 0.06$ & $0.63 \pm 0.04^{*}$ & $0.55 \pm 0.05^{*}$ \\
\hline & 400 & $0.22 \pm 0.01$ & $0.28 \pm 0.05$ & $0.48 \pm 0.09$ & $0.52 \pm 0.04^{\star *}$ & $0.45 \pm 0.07^{\star}$ \\
\hline \multirow[t]{2}{*}{ HSAL } & 200 & $0.22 \pm 0.01$ & $0.30 \pm 0.04$ & $0.52 \pm 0.06^{*}$ & $0.62 \pm 0.06^{\star *}$ & $0.53 \pm 0.05^{\star}$ \\
\hline & 400 & $0.18 \pm 0.01^{* *}$ & $0.25 \pm 0.02^{*}$ & $0.42 \pm 0.05^{\star}$ & $0.48 \pm 0.05^{\star *}$ & $0.42 \pm 0.06^{\star *}$ \\
\hline \multirow[t]{2}{*}{ HSW } & 200 & $0.27 \pm 0.04$ & $0.38 \pm 0.07$ & $0.68 \pm 0.08$ & $0.87 \pm 0.08$ & $0.83 \pm 0.09$ \\
\hline & 400 & $0.28 \pm 0.03$ & $0.42 \pm 0.04$ & $0.72 \pm 0.07$ & $0.88 \pm 0.07$ & $0.78 \pm 0.08$ \\
\hline
\end{tabular}

Values are expressed as mean \pm S.E.M. $(n=6) ;{ }^{*} p<0.05,{ }^{* *} p<0.01$ vs. control

$H S P E$, petroleum ether extract; $H S C H$, chloroform extract; HSAL, alcoholic extract; HSW, aqueous extract

Table 2: Effect of extracts of $H$. spinosa leaf on Brewer's yeast-induced pyrexia in rats

\begin{tabular}{|c|c|c|c|c|c|c|c|}
\hline \multirow{2}{*}{ Treatment } & \multirow{2}{*}{$\begin{array}{c}\text { Dose } \\
(\mathrm{mg} / \mathrm{kg})\end{array}$} & \multicolumn{6}{|c|}{ Rectal temperature in ${ }^{\circ} \mathrm{C}$ at various times $(\mathrm{h})$} \\
\hline & & $-18 h$ & $0 \mathrm{~h}$ & $1 \mathrm{~h}$ & $3 \mathrm{~h}$ & $5 \mathrm{~h}$ & $6 \mathrm{~h}$ \\
\hline Control & - & $37.33 \pm 0.08$ & $38.08 \pm 0.11$ & $38.30 \pm 0.09$ & $38.26 \pm 0.06$ & $38.25 \pm 0.09$ & $38.28 \pm 0.06$ \\
\hline \multirow[t]{2}{*}{ HSPE } & 200 & $37.52 \pm 0.10$ & $38.20 \pm 0.16$ & $38.43 \pm 0.16$ & $38.31 \pm 0.16$ & $38.25 \pm 0.16$ & $38.20 \pm 0.12$ \\
\hline & 400 & $37.20 \pm 0.12$ & $38.00 \pm 0.08$ & $38.01 \pm 0.09$ & $38.01 \pm 0.09$ & $38.05 \pm 0.05$ & $38.01 \pm 0.06$ \\
\hline \multirow[t]{2}{*}{$\mathrm{HSCH}$} & 200 & $37.82 \pm 0.09$ & $38.63 \pm 0.11$ & $38.48 \pm 0.06$ & $38.41 \pm 0.06$ & $38.38 \pm 0.09$ & $38.28 \pm 0.12$ \\
\hline & 400 & $37.35 \pm 0.16$ & $38.03 \pm 0.16$ & $37.73 \pm 0.23$ & $37.61 \pm 0.21^{*}$ & $37.63 \pm .21^{* *}$ & $37.41 \pm 0.26^{*}$ \\
\hline \multirow[t]{2}{*}{ HSAL } & 200 & $37.92 \pm 0.11$ & $38.78 \pm 0.03$ & $38.51 \pm .05^{\star *}$ & $38.38 \pm .09^{\star *}$ & $38.16 \pm .14^{* \star}$ & $38.10 \pm .14^{* \star}$ \\
\hline & 400 & $37.72 \pm 0.19$ & $38.55 \pm 0.14$ & $38.15 \pm 0.19^{*}$ & $38.11 \pm 0.20^{*}$ & $37.88 \pm .22^{* *}$ & $37.81 \pm .19^{* \star}$ \\
\hline \multirow[t]{2}{*}{ HSW } & 200 & $37.30 \pm 0.12$ & $38.03 \pm 0.14$ & $38.08 \pm 0.14$ & $38.03 \pm 0.16$ & $38.00 \pm 0.14$ & $37.95 \pm 0.15$ \\
\hline & 400 & $37.55 \pm 0.09$ & $38.28 \pm 0.19$ & $38.26 \pm 0.17$ & $38.18 \pm 0.14$ & $38.05 \pm 0.16$ & $38.01 \pm 0.16$ \\
\hline Paracetamol & 150 & $37.85 \pm 0.17$ & $38.70 \pm 0.15$ & $38.43 \pm 0.14^{*}$ & $38.25 \pm .12^{\star *}$ & $38.00 \pm .15^{\star *}$ & $37.87 \pm .18^{\star \star}$ \\
\hline
\end{tabular}

Values are expressed as mean \pm S.E.M. $(n=6) ;{ }^{*} p<0.05,{ }^{* *} p<0.01$ compared with 0 h of the same group HSPE, petroleum ether extract; $\mathrm{HSCH}$, chloroform extract; HSAL, alcoholic extract; HSW, aqueous extract

the leaves of $H$. spinosa. However, further investigations are required to isolate the active constituents responsible for these activities and to elucidate the exact mechanisms of action.

\section{Acknowledgment}

The authors are thankful to Dr. N. K. Dhal, Regional Research Laboratory, Bhubaneswar, India for the identification of the plant. 


\section{References}

1 The Ayurvedic Pharmacopoeia of India. Part I, vol. II, $1^{\text {st }}$ edn., Govt. of India, Ministry of Health \& Family Welfare, Department of ISM \& H, Delhi, The Controller of Publications, 1999, pp 88-94.

2 Sharma PC, Yelne MB, Dennis TJ. Database on medicinal plants used in ayurveda. vol. 4, New Delhi, Central Council for Research in Ayurveda \& Siddha, 2002, pp 320-331.

3 Chopra RN, Nayar SL, Chopra IC. Glossary of Indian Medicinal Plants. New Delhi, CSIR, 1986, pp 29.

4 Nadkarni KM. Indian Materia Medica. Bombay, India, Popular Prakashan, 1978, pp 667-669.

5 Mazumder UK, Gupta M, Maiti S, Mukherjee D. Antitumor activity of Hygrophila spinosa on Ehrlich ascites carcinoma and sarcoma- 180 induced mice. Indian J Exp Biol 1997; 35: 473477.

6 Boily $Y$, Vanpuyvelde L. Screening of medicinal plants of Rwanda (Central Africa) for antimicrobial activity. J Ethnopharmacol 1986; 16: 1-13.

7 Quasim C, Dutta NL. Chemical investigation of Asteracantha longifolia Nees. J Indian Chem Soc 1967; 44: 82-83.

8 Usha K, Kasturi GM, Hemlatha P. Hepatoprotective effect of Hygrophila spinosa and Cassia occidentalis on carbon tetrachloride induced liver damage in experimental rats. Indian $\mathrm{J} \mathrm{Cli}$ Biochem 2007; 22: 132-135.

9 Balraj P, Nagaraj S. Apigenin 7-oglucuronide from the flowers of Asteracantha longifolia Nees. Indian Drugs 1982; 19: 150-152.

10 Borgi W, Ghedira K, Chouchane N. Antiinflammatory and analgesic activities of Zizyphus lotus root barks. Fitoterapia 2007; 78: 16-19.

11 Vogel HG, Vogel WH. Drug Discovery and Evaluation. Verlag Berlin Heidelberg, New York, Springer, 1997, pp 390-417.

12 Akindele AJ, Adeyemi OO. Antiinflammatory activity of the aqueous leaf extract of Byrsocarpus coccineus. Fitoterapia 2007; 78: 25-25.

13 Dimo T, Fotio AL, Nguelefack TB, Asongalem EA, Kamtchouing P. Antiinflammatory activity of leaf extracts of Kalanchoe crenata Andr. Indian $J$ Pharmacol 2006; 38: 115-119.

14 Jain BB, Rathi BS, Thakurdesai PA, Bodhankar SL. Antipyretic activity of aqueous extract of leaves of Cocculus hirsutus. Indian J Nat Prod 2007; 23: $26-29$.

15 Metowogo K, Agbonon A, Eklu-Gadegbeku K, Aklikokou AK, Gbeassor M. Anti-ulcer and Antiinflammatory Effects of Hydro-alcohol Extracts of Aloe buettneri A. Berger (Lilliaceae). Trop J Pharm Res 2008; 7: 907-912.

16 Vinegar $R$, Schreiber $W$, Hugo $R$. Biphasic development of carrageenan oedema in rats. $J$ Pharmacol Exp Ther 1960; 166: 96-103.

17 Britto ARMS, Antonio MA.Oral anti-inflammatory and anti-ulcerogenic activities of a hydroalcoholic extract and partitioned fractions of Turnera ulmifolia (Turneraceae). J Ethnopharmacol 1998; 61: 215-228.

18 Saha A, Masud MA, Bachar SC, Kundu JK, Datta BK, Nahar L, Sarker SD. The analgesic and antiinflammatory activities of the extracts of Phyllanthus reticulatus. Pharmaceutical Biology 2007; 45: 335-359.

19 Hayare SW, Chandra S, Tandan SK, Sarma J, Lal J, Telang AG. Analgesic and antipyretic activities of Dalbergia sissoo leaves. Indian J Pharmacol 2000; 32: 357-360.

20 Patra A, Jha S, Murthy PN, Roy D, Sahu AN. Analgesic and antimotility activities of Hygrophila spinosa T. Anders. Pharmacologyonline 2008; 2: 821-828.

21 Mossa JS, Tariq M, Mohsin A, Ageel AM, Al-yahya MA, Al-said MS, Rafatullah S. Pharmacological studies on aerial parts of Calotropis procera Am j Chin med 1991; 19: 223-231.

22 Singh RK, Acharya SB, Bhattacharya SK. Pharmacological activity of Elaeocarpus sphaericus. Phytother Res 2000; 14: 36-39.

23 Al-said MS, Tariq M, Al-yahya MA, Rafatullah S, Ginnawi OT, Ageel AM. Studies on Ruta chalepensis, an ancient medicinal herb still used in traditional medicine. J Ethnopharmacol 1990; 28: 305-312. 